\title{
Statement by the Kommission OVAR of the AGO Study Group on the Use of HIPEC (Hyperthermic Intraperitoneal Chemotherapy) to Treat Primary and Recurrent Ovarian Cancer
}

\author{
Stellungsnahme der AGO Kommission OVAR zum Einsatz der HIPEC \\ (Hypertherme intraperitoneale Chemotherapie) beim primären und rezidivierten Ovarialkarzinom
}

Authors

Affiliations
P. Harter ${ }^{1}$, S. Mahner ${ }^{2}$, F. Hilpert ${ }^{3}$, I. Runnebaum ${ }^{4}$, O. Ortmann ${ }^{5}$, A. Mustea ${ }^{6}$, J. Sehouli ${ }^{7}$, A. du Bois ${ }^{1}$, U. Wagner ${ }^{8}$, for the Kommission Ovar of the Arbeitsgemeinschaft Gynäkologische Onkologie

The affiliations are listed at the end of the article

\section{Key words \\ ovarian cancer \\ statement \\ - HIPEC \\ - AGO}

Schlüsselwörter

- Ovarialkarzinom

- Empfehlung

- HIPEC

- AGO

\section{Abstract \\ $\nabla$}

HIPEC is offered to patients with ovarian, fallopian tube or primary peritoneal cancer at some hospitals. Altogether, there is still no evidence that HIPEC leads to an improvement of prognosis in any gynecologic tumor, neither in primary therapy nor in treatment of relapse. The available data indicate an increased complication rate which might negatively impact the benefit-risk balance of this procedure. In addition, standard treatment with proven efficacy might be withheld due to application of unproven methods. The use of HIPEC outside of well designed, prospective and controlled clinical trials is therefore disregarded.

\section{Zusammenfassung \\ $\nabla$}

Die HIPEC wird Patientinnen mit einer durch ein Ovarial-, Tuben-, oder primären Peritonealkarzinom bedingten Peritonealkarzinose an einigen Kliniken angeboten. Insgesamt gibt es jedoch keinen Nachweis, dass bei einem gynäkologischen Tumor durch Einsatz der HIPEC weder in der Primär- noch in der Rezidivsituation eine Verbesserung der Prognose erreicht werden kann. Aufgrund der derzeitigen Datenlage kann durch eine erhöhte Komplikationsrate auch eine Verschlechterung der Prognose nicht ausgeschlossen werden, insbesondere wenn hierdurch den Patientinnen eine erwiesenermaßen wirksame Standardtherapie vorenthalten wird. Daher wird von einer Durchführung der HIPEC außerhalb von prospektiven kontrollierten Studien abgeraten.

tion of the combination carboplatin-paclitaxel with the angiogenesis inhibitor bevacizumab.

The preclinical rationale for hyperthermic chemotherapy is based on studies which reported an increased cytotoxicity of cisplatin and other cytostatic drugs in human cell lines and animal models [6-10]. To explain this increased cytotoxicity it was suggested that higher temperatures could overcome cisplatin resistance [11]. Moreover, increased penetration of cisplatin administered intraperitoneally was described when combined with hyperthermia [12]. These theoretical approaches and preclinical observations are the basis for the clinical application of HIPEC. There are currently 3 published randomised studies on the use of HIPEC to treat advanced colon and gastric cancer. A randomised phase III trial for recurrent colorectal cancer in 105 patients investigated the efficacy of systemic therapy alone compared to a combination of cytoreductive surgery and HIPEC (mitomycin C), followed by systemic therapy. The trial demonstrated a significant benefit 
of combined therapy with respect to mean progression-free survival ( 7.7 vs. 12.6 months; $\mathrm{p}=0.020$ ) and mean disease-specific survival ( 12.6 vs. 22.2 months; $\mathrm{p}=0.028$ ). The strongest prognostic factor in this trial was postoperative residual tumour. Only patients with complete tumour resection benefited, while patients with residual tumour intraoperatively showed no benefit from HIPEC. Postoperative mortality in the experimental HIPEC arm was $8 \%[13,14]$. A further randomised study investigated the efficacy of surgery combined with HIPEC (cisplatin and mitomycin C) compared to surgery alone for peritoneal carcinomatosis of gastric cancer $(n=68)$. The rate of complete resections was $58 \%$ in both study arms. A significant benefit with regard to disease-specific survival (6.5 vs. 11.0 months; $\mathrm{p}=0.046$ ) was observed for surgery combined with HIPEC. No data was provided for overall survival. The strongest predictors in this study were the presence or absence of postoperative complications and completion of 6 cycles of postoperative chemotherapy. In absolute terms, patients who only underwent surgery with complete or almost complete resection (max. residual tumour $2.5 \mathrm{~mm}$ ) had the best prognosis with a mean disease-specific survival of 31 months, while the mean disease-specific survival for patients with complete resection and HIPEC was 12 months [15]. A three-arm randomised study of 139 patients with a primary diagnosis of locally advanced gastric cancer stage T2-T4 compared surgery alone vs. surgery + HIPEC vs. surgery + intraperitoneal chemotherapy. Peritoneal carcinomatosis was not a prerequisite condition for inclusion in the study. Subgroup analysis (serosa invasion or lymph node metastasis) found a benefit for HIPEC [16].

The use of HIPEC is primarily discussed for the therapy of peritoneal carcinomatosis. The different tumour biologies and therapeutic concepts make a highly differentiated approach necessary to take account of the different diagnoses. Studies have shown that peritoneal carcinomatosis from primary ovarian cancer has a different tumour biology and a significantly better overall prognosis compared to metastasised gastrointestinal tumours [17]. As the choice of systemic therapies to treat peritoneal metastases of gastrointestinal tumours is limited, HIPEC offers an additional option. But all studies to date have also highlighted an increase in postoperative complications such as infections, and the current S3 guideline on the treatment of gastric cancer therefore only recommends using HIPEC as part of a study (GoR A, LoE I) [18]. An update of the $\mathrm{S} 3$ guideline on colorectal cancer which includes an evaluation of HIPEC for this disease entity is still lacking.

Early peritoneal metastasis often occurs with ovarian cancer, and most patients are only diagnosed at an advanced stage of disease [19]. For primary surgery, postoperative residual tumour is the strongest independent predictor in addition to tumour stage [4]. The presence of peritoneal carcinomatosis often limits the efficacy of complete resection $[20,21]$. However, it has not been shown that peritoneal carcinomatosis is in itself an independent predictor [22]. Peritoneal carcinomatosis has been shown to be a negative predictor for complete resection in recurrent ovarian cancer. However, if complete resection of the tumour is achieved, then peritoneal carcinomatosis no longer serves as a prognostic factor $[23,24]$. Thus, peritoneal carcinomatosis of ovarian, fallopian tube or primary peritoneal cancer appears to be a technical obstacle to complete resection (and in this context has prognostic importance), but by itself it does not appear to be of biological importance and therefore does not require specific treatment with the exception of the appropriate surgical technique.

To date, there are no randomised studies on HIPEC in the context of primary surgery for ovarian cancer or surgery for recurrent ovarian cancer. Some retrospective data has been published as well as a few phase I/II trials with different, mostly platinumbased regimens, dosages and administration times [25]. There are no systematic studies on dosages. None of the studies to date have demonstrated a benefit of HIPEC with regard to overall survival times compared to surgery alone [26], and many studies reported significantly increased complication rates. In contrast to the limited data currently available on HIPEC, results of randomised phase III trials are available for normothermic intraperitoneal chemotherapy. A somewhat higher efficacy was observed for normothermic intraperitoneal chemotherapy regimens but this was accompanied by significantly increased side-effects, particularly for doses repeatedly administered intraperitoneally [27]. Due to the increased side-effects and the lower associated benefit as measured by the much lower rates of therapy completion, intraperitoneal therapy is not currently recommended as a standard option [28, 29].

In summary, there is currently no data available which shows an improvement in progression-free survival or overall survival after the use of HIPEC combined with cytoreductive surgery. Based on the available data, the increased rate of surgical complications means that HIPEC cannot be classified as practicable and safe. HIPEC should therefore not be used to treat ovarian, fallopian tube or primary peritoneal cancer outside prospective controlled studies, neither for primary therapy or to treat recurrence. This clear recommendation against the use of HIPEC has also been included in the most recent S3 guideline on the diagnosis and therapy of ovarian cancer and is based on an interdisciplinary consensus.

\section{Conflict of Interest \\ $\nabla$}

No conflict of interest.

\section{Affiliations}

${ }^{1}$ Kliniken-Essen-Mitte, Essen

${ }^{2}$ Universitätsklinikum Hamburg-Eppendorf, Hamburg

${ }^{3}$ Universitätsklinikum Schleswig Holstein, Campus Kiel, Kiel

${ }^{4}$ Universitätsklinikum Jena, Jena

${ }^{5}$ Universitätsklinikum Regensburg, Regensburg

${ }^{6}$ Universitätsklinikum Greifswald, Greifswald

7 Universitätsmedizin Berlin Charite, Berlin

${ }^{8}$ Universitätsklinikum Marburg, Marburg

\section{References}

1 Griffiths CT, Fuller AF. Intensive surgical and chemotherapeutic management of advanced ovarian cancer. Surg Clin North Am 1978; 58: 131-142

2 Harter P, Muallem ZM, Buhrmann C et al. Impact of a structured quality management program on surgical outcome in primary advanced ovarian cancer. Gynecol Oncol 2011; 121: 615-619

3 Bristow RE, Tomacruz RS, Armstrong DK et al. Survival effect of maximal cytoreductive surgery for advanced ovarian carcinoma during the platinum era: a meta-analysis. J Clin Oncol 2002; 20: 1248-1259

$4 \mathrm{du}$ Bois A, Reuss A, Pujade-Lauraine E et al. Role of surgical outcome as prognostic factor in advanced epithelial ovarian cancer: a combined exploratory analysis of 3 prospectively randomized phase 3 multicenter trials: by the Arbeitsgemeinschaft Gynaekologische Onkologie Studiengruppe Ovarialkarzinom (AGO-OVAR) and the Groupe d'Investigateurs Nationaux Pour les Etudes des Cancers de l'Ovaire (GINECO). Cancer 2009; 115: 1234-1244

5 Stuart GC, Kitchener H, Bacon M et al. 2010 Gynecologic Cancer InterGroup (GCIG) consensus statement on clinical trials in ovarian cancer: report from the Fourth Ovarian Cancer Consensus Conference. Int J Gynecol Cancer 2011; 21: 750-755

6 Hahn GM. Potential for therapy of drugs and hyperthermia. Canc Res 1979; 39: 2264-2268 
7 Meyn RE, Corry PM, Fletcher SE et al. Thermal enhancement of DNA damage in mammalian cells treated with cis-diamminedichloroplatinum(II). Cancer Res 1980; 40: 1136-1139

8 Alberts DS, Peng YM, Chen HS et al. Therapeutic synergism of hyperthermia-cis-platinum in a mouse tumor model. J Nat Cancer Inst 1980; 65: 455-461

9 Los G, van Vugt M,Pinedo HM. Response of peritoneal solid tumours after intraperitoneal chemohyperthermia treatment with cisplatin or carboplatin. Br J Cancer 1994; 69: 235-241

10 Akaboshi M, Tanaka Y, Kawai K et al. Effect of hyperthermia on the number of platinum atoms binding to DNA of HeLa cells treated with 195 mPt-radiolabelled cis-diaminedichloroplatinum(II). Int J Radiat Biol 1994; 66: 215-220

11 Herman TS, Teicher BA, Cathcart KN et al. Effect of hyperthermia on cisdiamminedichloroplatinum(II) (rhodamine 123)2[tetrachloroplatinum(II)] in a human squamous cell carcinoma line and a cis-diamminedichloroplatinum(II)-resistant subline. Cancer Res 1988; 48: 5101 5105

12 van de Vaart PJ, van der Vange $N$, Zoetmulder FA et al. Intraperitoneal cisplatin with regional hyperthermia in advanced ovarian cancer: pharmacokinetics and cisplatin-DNA adduct formation in patients and ovarian cancer cell lines. Eur J Cancer 1998; 34: 148-154

13 Verwaal VJ, van Ruth S, de Bree S et al. Randomized trial of cytoreduction and hyperthermic intraperitoneal chemotherapy versus systemic chemotherapy and palliatve surgery in patients with peritoneal carcinomatosis of colorectal cancer. J Clin Oncol 2003; 21: 3737-3743

14 Verwaal VJ, Bruin S, Boot H et al. 8-year follow-up of randomized trial: cytoreduction and hyperthermic intraperitoneal chemotherapy versus systemic chemotherapy in patients with peritoneal carcinomatosis of colorectal cancer. Ann Surg Oncol 2008; 15: 2426-2432

15 Yang XJ, Huang CQ Suo T et al. Cytoreductive surgery and hyperthermic intraperitoneal chemotherapy improves survival of patients with peritoneal carcinomatosis from gastric cancer: final results of a phase III randomized clinical trial. Ann Surg Oncol 2011; 18: 1575-1581

16 Yonemura Y, de Aretxabala X, Fujimura T et al. Intraoperative chemohyperthermic peritoneal perfusion as an adjuvant to gastric cancer: final results of a randomized controlled study. Hepatogastroenterology 2001; 48: 1776-1782

17 Heiss MM, Murawa P, Koralewski $P$ et al. The trifunctional antibody catumaxomab for the treatment of malignant ascites due to epithelial cancer: Results of a prospective randomized phase II/III trial. Int J Cancer 2010; 127: 2209-2221
18 S3 Leitlinie Magenkarzinom 13.06.2012; AWMF-Register-Nummer (032-009OL)

19 Robert Koch-Institut und die Gesellschaft der epidemiologischen Krebsregister in Deutschland e.V., Hrsg. Krebs in Deutschland 2007/2008. 8. Ausgabe. Berlin: 2012; 8: 76-79

$20 \mathrm{Brand} A H$. Ovarian cancer debulking surgery: a survey of practice in Australia and New Zealand. Int J Gynecol Cancer 2011; 21: 230-235

21 Beutel B, Heitz F, Harter P et al. Was sind die Gründe für postoperativen Tumorrest beim fortgeschrittenen Ovarialkarzinom FIGO IIIB-IV[OC] bei OP in einem spezialisierten Zentrum. Arch Gynecol Obstet 2012; 286 (Suppl. 1): S113

22 Heitz J, Harter P, Meier W et al. Chirurgische Komplettresektion versus medikamentöse Komplettremission bei fortgeschrittenem Ovarialkarzinom FIGO IIB-IV. Arch Gynecol Obstet 2012; 286 (Suppl. 1): S98

23 Harter P, Hahmann $M$, Lueck $H J$ et al. Surgery for recurrent ovarian cancer: role of peritoneal carcinomatosis: exploratory analysis of the DESKTOP I Trial about risk factors, surgical implications, and prognostic value of peritoneal carcinomatosis. Ann Surg Oncol 2009; 16: 13241330

24 Fotopoulou C, Zang R, Gultekin M et al. Value of tertiary cytoreductive surgery in epithelial ovarian cancer: an international multicenter evaluation. Ann Surg Oncol 2012; Oct 2 [Epub ahead of print]

25 Bijelic L, Jonson A, Sugarbaker PH. Systematic review of cytoreductive surgery and heated intraoperative intraperitoneal chemotherapy for treatment of peritoneal carcinomatosis in primary and recurrent ovarian cancer. Ann Oncol 2007; 18: 1943-1950

26 Harter P, Heitz F, du Bois A. Surgery for relapsed ovarian cancer: when should it be offered? Curr Oncol Rep 2012; 14: 539-543

27 Armstrong DK, Bundy B, Wenzel $L$ et al. Intraperitoneal cisplatin and paclitaxel in ovarian cancer. N Engl J Med 2006; 354: 34-43

28 Gore $M$, $d u$ Bois A, Vergote I. Intraperitoneal chemotherapy in ovarian cancer remains experimental. J Clin Oncol 2006; 24: 4528-4530

29 du Bois A, Schmalfeldt B, Meier W et al.; für die Kommission Ovar der AGO, die AGO-Studiengruppe Ovarialkarzinom (AGO-OVAR) und die NOGGO. Ovarialkarzinom: Intraperitoneale Therapie ist nicht der neue Standard. Frauenarzt 2006; 47: 510-512

Deutschsprachige Zusatzinformationen online abrufbar unter: www.thieme-connect.de/ejournals/toc/gebfra. 